\title{
Silurian Xiangyang island-arc gabbro in the Jiamusi-Khanka Block, NE China: Implications for the geodynamic evolution of the eastern Paleo-Asian Ocean
}

\author{
HAO YANG*, WENCHUN GE \\ College of Earth Sciences, Jilin University, Changchun \\ 130061, China (*correspondence: yanghao@jlu.edu.cn)
}

There is a broad consensus that the Solonker-Yanji suture zone (SYZ) marks the final closure of the Paleo-Asian Ocean during the Late Permian to Middle Triassic. However, the tectonic properties of the early Paleozoic arcs surrounding the SYZ and the early subduction polarity of oceanic basins still remain controversial. In this contribution, we present zircon $\mathrm{U}-\mathrm{Pb}$ ages, major and trace elements, and $\mathrm{Sr}-\mathrm{Nd}-\mathrm{Hf}-\mathrm{O}$ isotopic compositions of newly discovered early Paleozoic gabbro in the central Jiamusi-Khanka Block and to the southeast of the Dunhua-Mishan fault, aiming to address the issue. SIMS and LA-ICP-MS U-Pb dating data of zircons from two gabbro samples indicate they were emplaced at 439 Ma. The Silurian Xiangyang hornblende gabbros are calc-alkaline with high $\mathrm{Na}_{2} \mathrm{O}$ contents and relatively low $\mathrm{La} / \mathrm{Yb}, \mathrm{Th} / \mathrm{Yb}$ and $\mathrm{Nb} / \mathrm{Yb}$ ratios. They are characterized by enrichment in light rare earth elements, large ion lithophile elements, $\mathrm{Sr}, \mathrm{Eu}$, and $\mathrm{Ba}$, and depletion in high field strength elements (e.g., $\mathrm{Nb}, \mathrm{Ta}, \mathrm{Ti}, \mathrm{Zr}$, and $\mathrm{Hf}$ ). They have high initial ${ }^{87} \mathrm{Sr}{ }^{86} \mathrm{Sr}(0.70773$ to 0.70774$)$ and negative $\varepsilon N d(t)(-1.0$ to $1.5)$, with relatively high zircon $\delta^{18} \mathrm{O}(+5.5 \%$ to $+7.9 \%)$ and variable $\varepsilon \mathrm{Hf}(\mathrm{t})(-1.3$ to +4.1$)$. The geochemical evidence suggest that the Xiangyang gabbros were derived by low degree melting of a lithospheric mantle wedge that had been extensively modified by fluids from low temperature altered oceanic crust and sediments. The primary magma subsequently underwent both fractional crystallization of clinopyroxene + hornblende + zircon and accumulation of olivine + plagioclase with negligible crustal contamination. All these features, together with tectonic discrimination results, indicate that the Silurian Xiangyang gabbros formed in an island arc setting, and can be well correlated with the 520-420 Ma Bainaimiao-Siping arc belt. Considering the spatial relations among the island arcs, Dunhua-Mishan fault, and SYZ, we invoke that the Xiangyang gabbros were initially generated by the northward intra-oceanic subduction within the eastern Paleo-Asian Ocean during the Early Silurian, and then at ca. $161 \mathrm{Ma}$, they were moved northeastwards more than $200 \mathrm{~km}$ to the present location due to the left-lateral strike-slip Dunhua-Mishan Fault.

This research was financially supported by the Natural Science Foundation of China (41802049). 